\title{
Perancangan Sistem Penjadwalan Perkuliahan Berbasis Website Menggunakan Algortima Genetika
}

\author{
Arif Prio Pambudi*1, Ari Waluyo ${ }^{2}$, El Vionna Laellyn Nurul Fatich ${ }^{3}$ \\ ${ }^{1,2}$ Politeknik Dharma Patria Kebumen; Jl. Letjend. Suprapto 73 Kebumen, Telp (0287) \\ 381166 \\ ${ }^{3}$ Universitas Gadjah Mada; Jl. Grafika No.2, Mlati, Yogyakarta, Telp (0274) 552305 \\ e-mail: *1arifprio9@gmail.com, ${ }^{2}$ ari@ politeknik-kebumen.ac.id, \\ elvionna95@mail.ugm.ac.id
}

\begin{abstract}
Abstrak
Penjadwalan merupakan sebuah upaya pengelolaan waktu terhadap suatu kegiatan dengan tujuan kelancaran dan keberlangsungan kegiatan tersebut. Salah satu penjadwalan yang sangat diperhatikan adalah penjadwalan perkuliahan. Penjadwalan perkuliahan pada Politeknik Dharma Partria Kebumen dilakukan secara komputerisasi dengan aplikasi Microsoft Excel. Hal ini dinilai kurang efektif karena dibutuhkan tingkat ketelitian yang tinggi supaya tidak terjadi bentrok dalam jadwal perkuliahan, serta proses yang panjang, kurang sederhana, dan waktu yang lama. Berdasarkan masalah tersebut, dibutuhkan sebuah sistem penjadwalan perkuliahan yang memanfaatkan algoritma genetika sebagai metode otomasi. Metode pengembangan sistem pada penelitian ini ialah metode konvensional, waterfall, dengan permodelan sistem Undifinied Modeling Languade (UML). Berdasarkan hasil uji coba sistem penjadwalan, didapatkan waktu paling efektif untuk proses penjadwalan perkuliahan adalah 00:12:17 pada nilai populasi 10, Pm 0,4, dan Pc 0,7. Setelah dirancanganya sistem informasi penjadwalan perkuliahan berbasis website menggunakan algoritma gentika, proses penjadwalan perkuliahan pada setiap awal semester dapat dilakukan dengan akurat, cepat, efisien, dan efektif.
\end{abstract}

Kata kunci_algoritma genetika, penjadwalan perkuliahan, website

\begin{abstract}
Scheduling is an effort to manage time for an activity to smoothness and continuity of the activity. One of the scheduling that is very concerned is the schedule of lectures. At Politeknik Dharma Patria Kebumen, the lecture scheduling process is computerized with the Microsoft Excel application. The system is considered less effective because it requires a high accuracy so that there are no clashes in the lecture schedule, and the process is long and takes a long time. A website-based lecture scheduling information system is needed based on these problems by utilizing genetic algorithms as an automation method. In comparison, waterfall is used in this information system development, with the system modelling using the Undefined Modeling Language (UML). Based on the scheduling system trial results, the most effective time for the lecture scheduling process was 00:12:17 with a population value of $10, \mathrm{Pm}$ value of 0.4 , and Pc value of 0.7. After designing a website-based lecture scheduling information system using the genetic algorithm, the lecture scheduling process can be carried out quickly, accurately, effectively, and efficiently at the beginning of each semester.
\end{abstract}

Keywords—genetic algorithm, lecture scheduling, website 


\section{PENDAHULUAN}

$\mathrm{S}$ aat ini, teknologi informasi telah berkembang sangat pesat dan memberikan keuntungan bagi kegiatan manusia. Pemanfaatan teknologi informasi tersebut meliputi bidang pendidikan, kesehatan, pemerintahan, ekonomi dan bisnis, serta bidang-bidang lainnya [1]. Salah satu hasil perkembangan teknologi informasi adalah terciptanya kecerdasan komputer yang dapat meniru kerja manusia, yang disebut dengan kecerdasan buatan (Artificial Intelligence). Kecerdasan buatan mampu membantu memecahkan masalah yang rumit, bahkan terkadang dapat menyelesaikan masalah lebih cepat dan andal dibandingkan dengan hasil pemecahan masalah oleh manusia sendiri [2].

Salah satu pemanfaatan kecerdasan buatan ini adalah pemecahan masalah penjadwalan. Penjadwalan merupakan sebuah upaya pengelolaan waktu terhadap suatu kegiatan, dengan tujuan kelancaran dalam keberlangsungan kegiatan tersebut [3]. Sedangkan penjadwalan adalah proses pembuatan jadwal yang dilakukan sebaik-baiknya dan memenuhi keinginan untuk peningkatkan efektifitas penggunaan sumber daya [4]. Dalam proses penjadawalan perkuliahan terdapat dua aspek yang harus diperhatikan dalam pemenuhan batasan, yakni hard constraint dan soft constraint. Batasan yang harus dihindari dan tidak boleh dilanggar untuk menerapkan proses penjadwalan perkuliahan disebut dengan hard constraint. Sedangkan soft constraint adalah batasan yang dapat ditoleransi, namun tetap menjadi acuan dalam proses penjadwalan perkuliahan [3][4][5][6][7].

Pada Politeknik Dharma Patria Kebumen, kegiatan penjadwalan perkuliahan telah dilakukan secara komputerisasi, yakni dengan menggunakan program Microsoft Excel. Hal tersebut dirasa kurang optimal, karena persamaan penggunaan kelas, persamaan jadwal mengajar dosen, mata kuliah yang sama pada kelas yang sama dalam satu hari, serta kendala lainnya sangat mungkin terjadi saat proses penjadwalan dilakukan tanpa sistem informasi yang mendukung optimasi proses penjadwalan. Waktu yang relatif lama, proses yang panjang, dan membutuhkan tingkat ketelitian yang tinggi merupakan hal-hal yang sering menjadi penghambat dalam proses penjadwalan di Politeknik Dharma Patria Kebumen.

Berdasarkan permasalahan tersebut, maka perlu di rancang sebuah sistem informasi penjadwalan untuk mempercepat serta mengoptimasi proses penyusunan jadwal perkuliahan. Dengan menerapkan sistem informasi penjadwalan berbasis website, proses penjadwalan dapat dilakukan dengan cepat, akurat, efektif, dan efisien [8]. Sistem informasi yang dirancang berbasis website menjadikan proses penjadwalan dapat dilaksanakan secara online, yakni dapat diakses dimanapun dan kapanpun [9]. Hal ini dirasa sangat efektif dan efisien, terlebih ketika akses pekerjaan di kampus dibatasi atau pada saat Work From Home.

Sedangkan dalam permasalahan optimasi (optimization problem), dibutuhkan adanya solusi yang optimum atau yang paling sesuai dengan permasalahan yang ada [3]. Terdapat dua metode yang dapat diterapkan dalam permasalahan optimasi, yakni metode konvensional dan metode heuristik. Metode dengan perhitungan matematika murni untuk menyelesaikan permasalahan optimasi disebut metode konvensional. Contoh metode konvensional ini adalah algoritma Djikstra, Bellman-Ford, dan Floyd-Warshall. Sedangkan metode yang sudah menggunakan bantuan kecerdasan buatan untuk penyelesaian masalah optimasi dikenal dengan istilah metode heuristik. Contoh metode heuristik yakni algoritma genetika, jaringan saraf tiruan, algoritma pencarian tabu, dan algortima dengan kecerdasan buatan lainnya [5]. 
Berdasarkan hasil analisis karakteristik permasalahan optimasi penjadwalan perkuliahan di Politeknik Dharma Patria Kebumen, metode heuristik yang dapat diterapkan dalam sistem informasi penjadwalan perkuliahan adalah algortima genetika. Algoritma genetika merupakan algoritma yang poluler digunakan dalam kecerdasan buatan, terutama dalam pemecahan masalah penjadwalan [10]. Algoritma ini dikembangkan atas dasar inspirasi proses evolusi ilmiah, yakni proses algoritma yang setiap individunya melakukan tahapan evolusi seperti seleksi, mutasi, hingga kawin silang atau crossover. Tujuan dari dilakukannya proses tersebut adalah terciptanya individu terbaru dari setiap generasi, dimana individu yang baru tersebut dapat memecahkan masalah penjadwalan perkuliahan [2].

Pokok permasalahan yang didapatkan dari latar belakang di atas adalah bagaimana merancang sebuah sistem informasi penjadwalan perkuliahan berbasis website menggunakan algoritma genetika yang mampu mengoptimasi proses penjadwalan pada Politeknik Dharma Patria Kebumen.

\section{METODE PENELITIAN}

\subsection{Metode Pengembangan Sistem}

Metode waterfall merupakan metode pengembangan sistem yang digunakan dalam perancangan sistem informasi penjadwalan perkuliahan ini. Terdapat setidaknya lima tahapan dalam metode waterfall yang digunakan dalam perancangan sistem informasi penjadwalan perkuliahan [11].

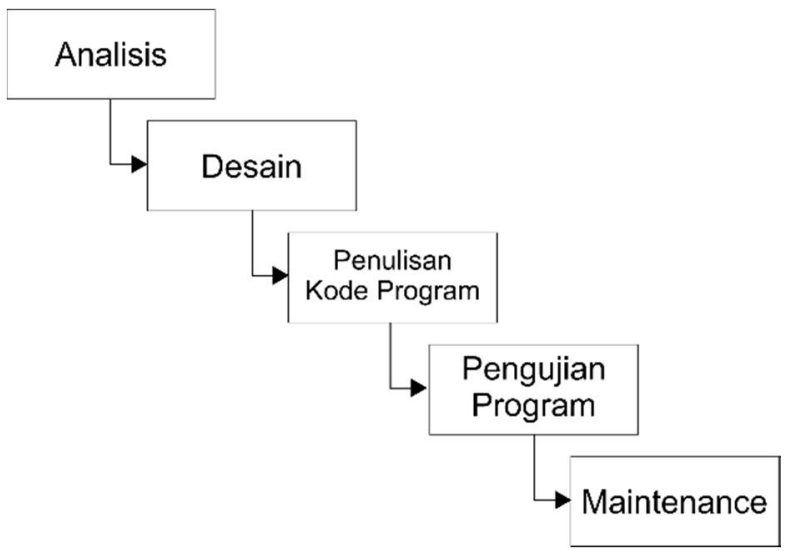

Gambar 1. Metode Waterfall

\subsubsection{Analisis}

Tahap yang dilakukan pertama kali dalam perancangan sistem informasi penjadwalan perkuliahan adalah analisis. Analisis ini meliputi analisis masalah yang ditemukan pada sistem yang ada saat ini, analisis kebutuhan, dan analisis sistem. Hal-hal yang dibutuhkan dalam merancang sistem informasi penjadwalan perkuliahan dikumpulkan melalui wawancara kepada dihak akademik Politeknik Dharma Patria Kebumen. Setelah seluruh bahan di dapatkan, maka tahap selanjutnya adalah desain sistem sesuai kebutuhan. 


\subsubsection{Desain}

Pada desain terdiri atas empat fase, yaitu (1) desain alur sistem menggunakan UML, (2) desain tampilan interface, (3) desain algoritma, dan (4) desain database.

\subsubsection{Penulisan Kode Program}

Setelah dilakukan tahap desain, tahap selanjutnya adalah menerjemahkan desain tersebut dalam bahasa pemrograman PHP dan database MySQL. Kode program dibangun untuk menjalankan aplikasi berdasarkan logika yang telah diterjemahkan dan disesuaikan tampilan interface yang telah dirancang.

\subsubsection{Pengujian Program}

Setelah seluruh sistem dirancang, tahap yang harus dilakukan adalah melakukan pengujian untuk memastikan sistem informasi yang telah dirancang tersebut sesuai dengan kebutuhan. Pengujian sistem yang digunakan dalam perancangan sistem informasi penjadwalan perkuliahan ini ialah pengujian blackbox. Pengujian blackbox berfokus pada kesesuaian fungsi dengan kebutuhan dan persyaratan fungsional perangkat lunak [12]. Adapun proses dalam pengujian blackbox yang dilakukan adalah dengan membuat himpunan kondisi masukan (input), kemudian diuji seluruh syarat fungsional dalam sistem informasi penjadwalan tersebut.

\subsubsection{Maintenance}

Setelah sistem informasi penjadwalan perkuliahan diimplementasikan, maka tahap selanjutnya adalah perawatan (maintenance). Perawatan digunakan agar sistem dapat terus berjalan dan dapat dikembangkan ke versi-versi selanjutnya.

\subsection{Metode Algoritma Genetika}

Adapun alur proses dalam algoritma genetika dapat dilihat pada Gambar 2. 


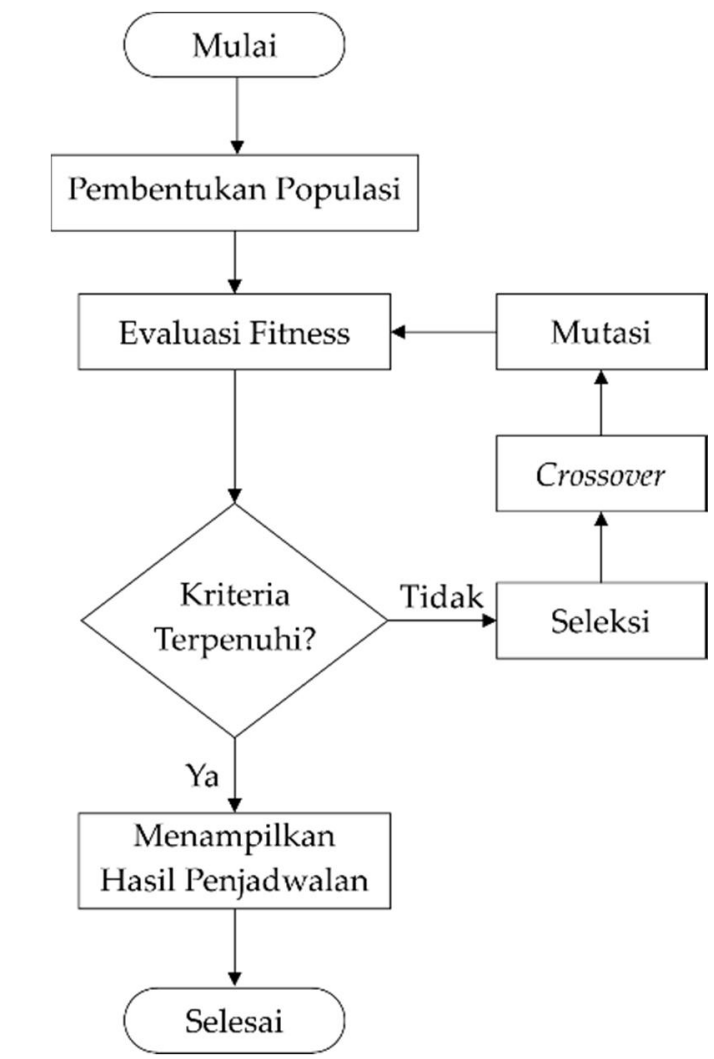

Gambar 2. Flowchart Algoritma Genetika

\subsubsection{Pembentukan Populasi}

Proses algoritma genetika diawali dengan penentuan set solusi bernama populasi. Solusi tersebut diwakili oleh kromosom [13]. Kromosom tersebut ditampilkan dalam bentuk array atau larik yang berisi data pendukung dalam proses penjadwalan. Jumlah gen yang dibentuk merupakan panjang dari kromosom [6]. Setelah kromosom ditentukan, tahap selanjutnya adalah evaluasi nilai fitness dari kromosom dan penentuan probabilistik yang sesuai dengan nilai fitness pada setiap kromosom. Kromosom yang telah dipilih secara acak, kemudian dikawinkan untuk mendapatkan keturunan, crossover dan mutasi. Proses evolusi akan diulang sampai kondisi sesuai dengan kebutuhan sistem.

\subsubsection{Batasan Penjadwalan}

Proses algoritma genetika diawali dengan penentuan set solusi bernama populasi. Solusi tersebut diwakili oleh kromosom [13]. Kromosom tersebut ditampilkan dalam bentuk array atau larik yang berisi data pendukung dalam proses penjadwalan. Jumlah gen yang dibentuk merupakan panjang dari kromosom [6]. Setelah kromosom ditentukan, tahap selanjutnya adalah evaluasi nilai fitness dari kromosom dan penentuan probabilistik yang sesuai dengan nilai fitness pada setiap kromosom. Kromosom yang telah dipilih secara acak, kemudian dikawinkan untuk mendapatkan keturunan, crossover dan mutasi. Proses evolusi akan diulang sampai kondisi sesuai dengan kebutuhan sistem.

a. Hard constraint: batasan yang tidak boleh dilanggar dalam proses penjadwalan perkuliahan. Adapun hard constraint dalam sistem informasi perjadwalan perkuliahan yakni: 
1) Seorang dosen tidak dapat mengajar mata kuliah di ruang yang sama dengan waktu yang bersamaan pula.

2) Sebuah ruang hanya boleh digunakan untuk satu mata kuliah dan kelas pada satu waktu yang sama.

3) Suatu kelas hanya boleh mengikuti mata kuliah dan menempati satu ruang pada satu waktu yang sama.

4) Ruang teori hanya untuk mata kuliah yang bersifat teori, dan praktikum menempati lab. Praktikum.

5) Hari aktif perkuliahan Senin sampai Sabtu.

6) Perkuliahan hanya dapat diselenggarakan dalam sesi waktu kuliah yang disediakan.

b. Soft constraint: batasan yang mendapat toleransi dalam proses penjadwalan perkuliahan. Adapun soft constraint dalam sistem informasi perjadwalan perkuliahan yakni:

1) Dosen dapat mengatur sendiri ketersediaan waktu mengajar.

2) Prioritas penjadwalan untuk waktu ketersediaan mengajar dosen.

3) Seorang dosen boleh mengajar dua atau lebih mata kuliah dihari yang sama.

4) Terdapat dua atau lebih mata kuliah yang berbeda pada hari yang sama untuk satu kelas.

5) Mata kuliah yang sama, namun mungkin diambil oleh beberapa angkatan yang berbeda, dijadwalkan dalam waktu yang berbeda.

\subsubsection{Evaluasi Fitness dan Seleksi}

Evaluasi fitness berfungsi untuk menentukan nilai fitness pada setiap kromosom, setelah itu mengevaluasinya terus menerus hingga terpenuhi suatu kriteria yang diharapkan. Dalam teori evolusi alam, nilai fitness rendah yang dimiliki suatu individu tidak akan bertahan dan akan mati. Sebagai solusi permasalahan optimasi, perlu dicari nilai maksimal dari sebuah fitness, sehingga didapatkan nilai fitness terbaik yang digunakan sebagai nilai dalam fungsi tersebut [14].

Untuk tahap seleksi, terdapat dua metode yang dapat digunakan, yakni metode permainan Roulette-wheel dan seleksi ranking. Pada metode Roulette-wheel, kromosom menempati posisi yang ada pada lingkarang roda Roulette sesuai dengan nilai fitness, kemudian diacak seperti pada permainan Roulette-wheel. Sedangkan untuk seleksi ranking, kromosom diurutkan berdasarkan nilai fitness kemudian dipilih secara urutan [14].

Untuk menghubungkan fungsi fitness dan Roulette-wheel dalam pemilihan kromosom, fungsi fitness digunakan sebagai nilai probabilitas kromosom yang bersangkutan, dengan rumus seperti berikut ini [13]:

$$
\text { probabilitas kromosom }=\frac{1}{\text { fitness }}(1)
$$

\subsubsection{Kawin Silang (Crossover)}

Crossover dalam algoritma genetika merupakan proses penambahan keanegaragaman anak (offspring) suatu populasi dengan menggabungkan dua kromosom parent pada satu waktu [14]. Proses paling sederhana dari crossover adalah dengan mengkombinasikan segmen dari salah satu induk ke induk yang lainnya secara acak, yakni dengan cara memilih titik yang akan dipisahkan, kemudian memasang titik tersebut pada bagian kanan segmen salah satu induk, dan meletakkan titik lainnya pada bagian kiri segmen induk yang lainnya [5]. 


\subsubsection{Mutasi}

Terdapat dua cara yang dapat dilakukan dalam proses mutasi, yakni dengan penukaran (swap) dan acak (random). Pada cara pertama adalah dengan menukar secara langsung nilai dari gen yang ada dengan menentukan sendiri letaknya. Sedangkan untuk cara acak atau random dengan menukar nilai gen yang akan dimutasi secara acak untuk mendapatkan nilai yang baru, tanpa menentukan terlebih dahulu posisinya [15]. Dalam penelitian ini digunakan mutasi random. Syarat dalam proses pemilihan individu untuk mutasi ini adalah dengan mempertimbangkna nilai mutation rate. Mutation rate yang nantinya akan menentukan suatu individu layak atau tidak untuk dilakukan mutasi [6].

\subsubsection{Data Pendukung Penjadwalan}

Data-data yang diperlukan untuk mendukung proses penjadwalan perkuliahan ini antara lain adalah data dosen, mata kuliah, runag, jam atau sesi, hari, dan pengampu mata kuliah. Berdasarkan hasil pencarian dengan narasumber pihak akademik Politeknik Dharma Patria Kebumen, didapatkan rincian jumlah data pendukung seperti pada Tabel 1.

Tabel 1. Jumlah Data Pendukung Penjadwalan

\begin{tabular}{|l|c|}
\hline \multicolumn{1}{|c|}{ Data } & Jumlah Data \\
\hline Dosen & 37 \\
\hline Mata Kuliah & 65 \\
\hline Ruang & 12 \\
\hline Jam & 9 \\
\hline Hari & 6 \\
\hline Pengampu & 65 \\
\hline
\end{tabular}

\section{HASIL DAN PEMBAHASAN}

\subsection{Use Case Diagram Usulan Sistem Penjadwalan}




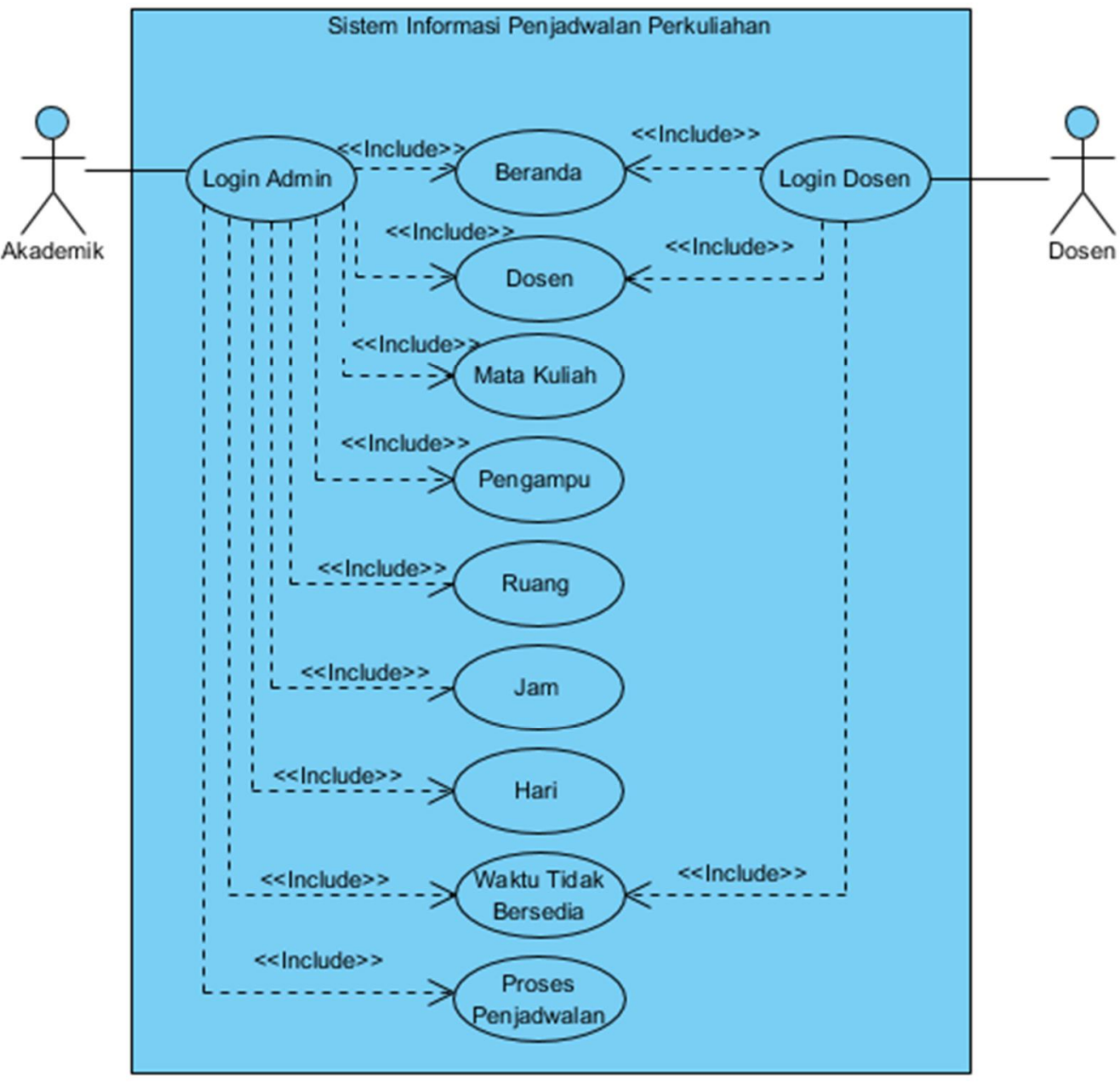

Gambar 3. Use Case Diagram Usulan Sistem Informasi Penjadwalan Perkuliahan

Pada Gambar 3 dapat dilihat, actor dalam sistem informasi penjadwalan perkuliahan ada dua, yakni akademik dan dosen. Akademik mengelola seluruh use case yang terlibat dalam sistem informasi penjadwalan perkuliahan, sedangkan dosen hanya dapat mengelola data dosen milik dosen tersebut secara pribadi dengan melakukan login tersebut. Pengelolaan data yang dilakukan akademik adalah menambah data, mengubah, dan menghapus data pendukung dalam sistem informasi penjadwalan perkuliahan ini. Keunikan proses dalam pengelolaan data terdapat pada saat proses penjadwalan yang dijelaskan melalui activity diagram proses penjadwalan pada Gambar 4. 


\subsection{Activity Diagram Proses Penjadwalan Perkuliahan}

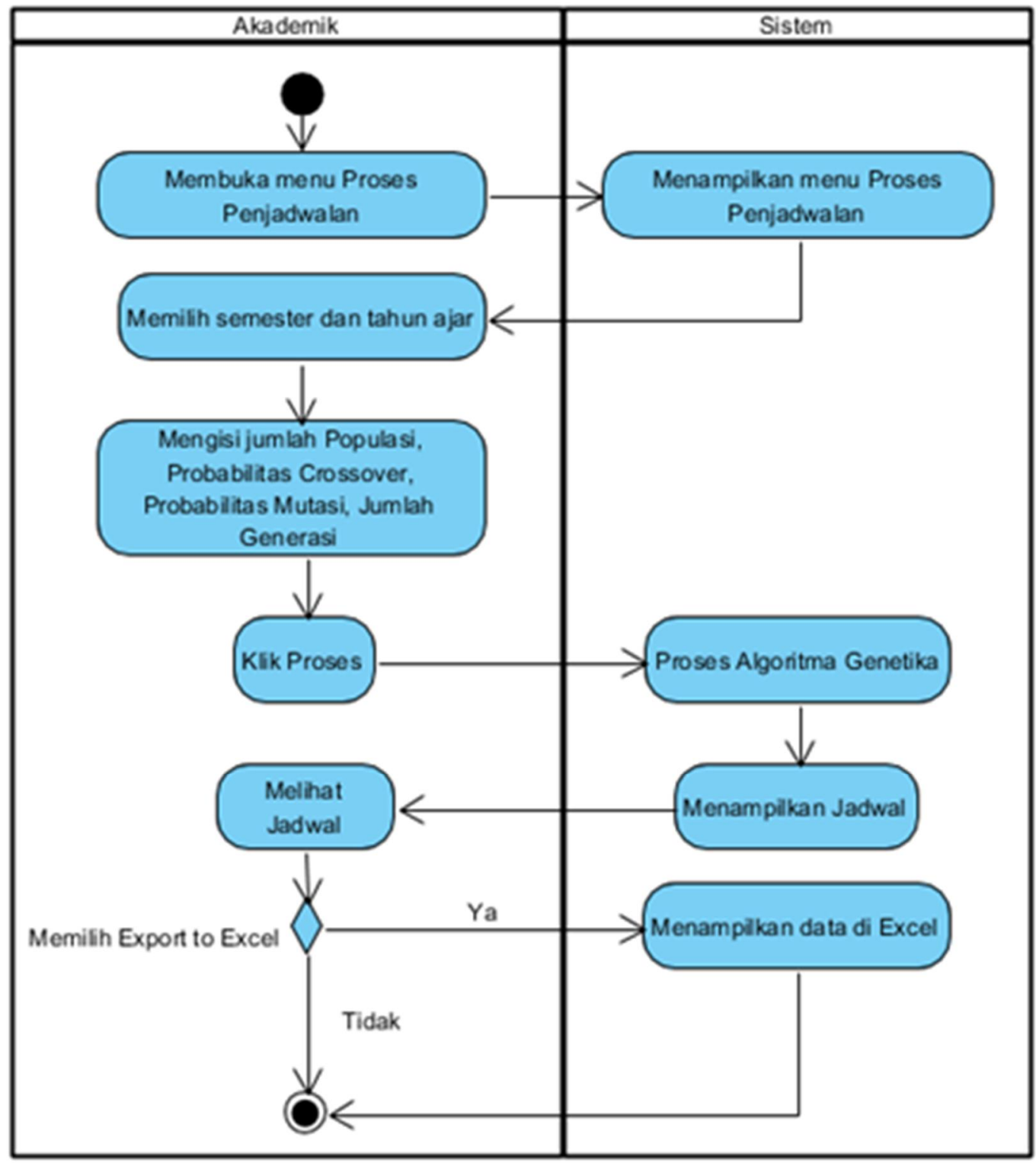

Gambar 4. Activity Diagram Proses Penjadwalan Perkuliahan

Proses penjadwalan perkuliahan dapat dilakukan dengan baik jika seluruh data pada data pendukung telah dilengkapi. Pada Gambar 4 dapat dilihat alur proses penjadwalan yang dilakukan secara otomatis menggunakan algoritma genetika. Sebelum proses generate, akademik harus mengisi jumlah populasi, probabilitas mutasi, probabilitas crossover, dan jumlah generasi. Lama proses generat tergantung pada jumlah data dan kesesuaian dengan nilai populasi, probabilitas mutasi, probabilitas crossover, dan nilai generasi yang diinputkan. 


\subsection{Class Diagram Penjadwalan Perkuliahan}

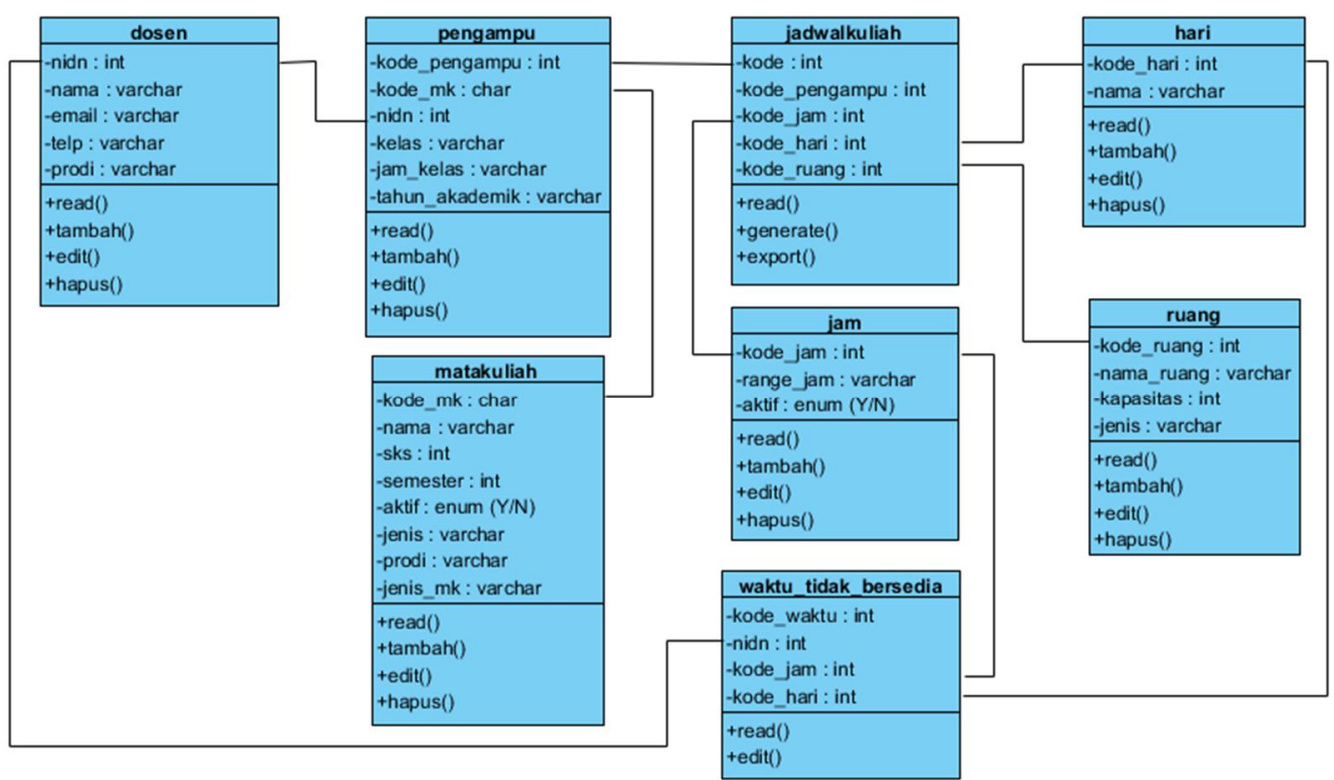

Gambar 5. Class Diagram Proses Penjadwalan Perkuliahan

\subsection{Output Sistem}

Pada Gambar 6 - 11 ditampilkan hasil output sistem berupa interface halaman data pendukung sistem informasi penjadwalan perkuliahan menggunakan algoritma genetika.

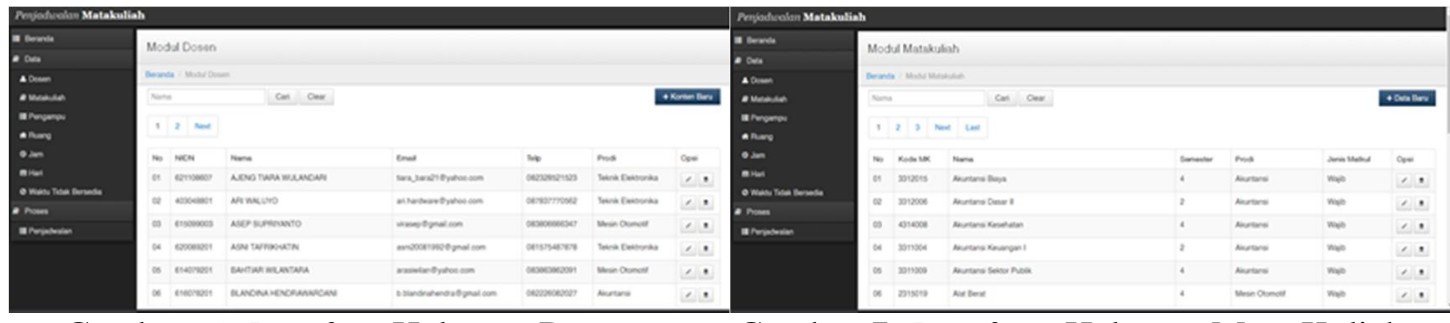

Gambar 6. Interface Halaman Dosen

Gambar 7. Interface Halaman Mata Kuliah
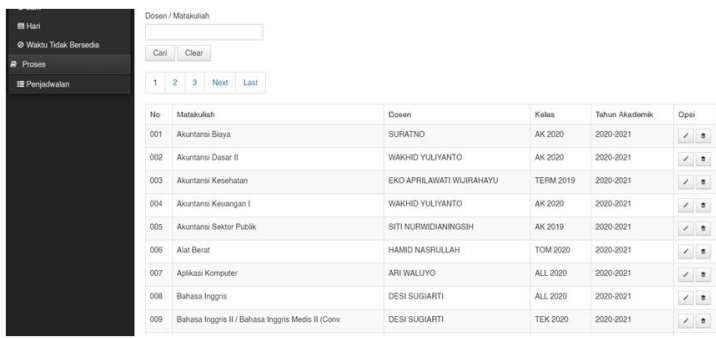

Gambar 8. Interface Halaman Pengampu

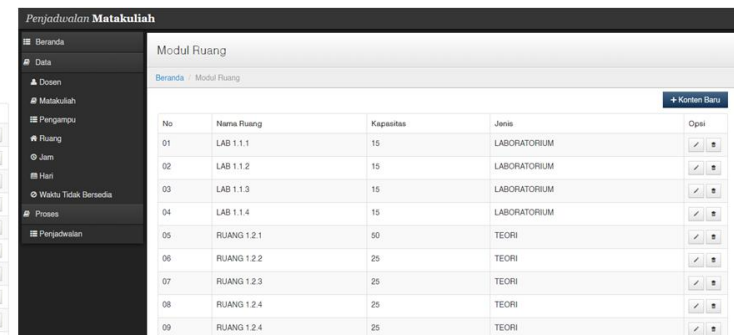

Gambar 9. Interface Halaman Ruang

Arif, et., al [Perancangan Sistem Penjadwalan Perkuliahan Berbasis Website Menggunakan Algortima Genetika] 


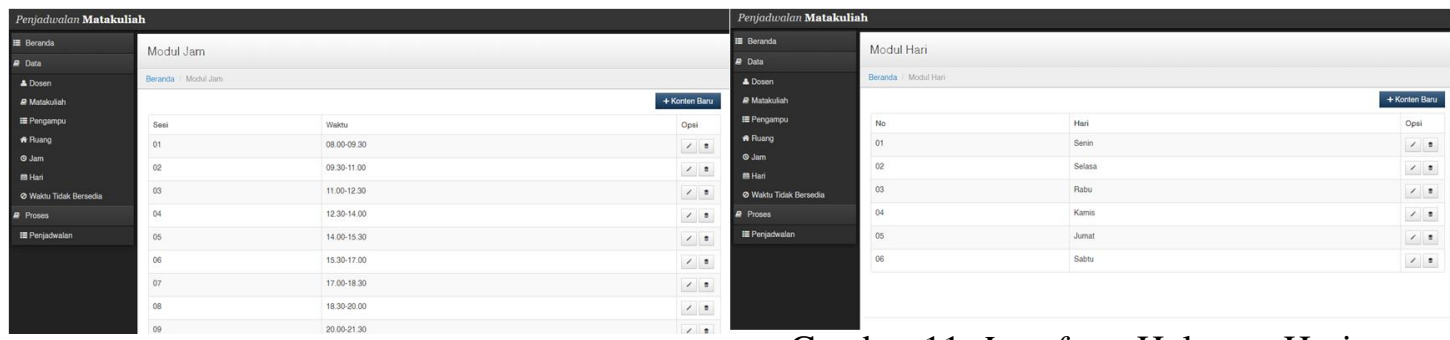

Gambar 10. Interface Halaman Jam

Gambar 11. Interface Halaman Hari

Setelah seluruh data pendukung diinputkan, tahap selanjutnya adalah proses generate jadwal perkulihan. Pada tahap ini, pengujian sistem dilakukan dengan mengubah jumlah populasi, probabilitas mutasi, probabilitas crossover, dan jumlah generasi untuk mendapatkan nilai yang paling sesuai dalam proses penjadwalan.

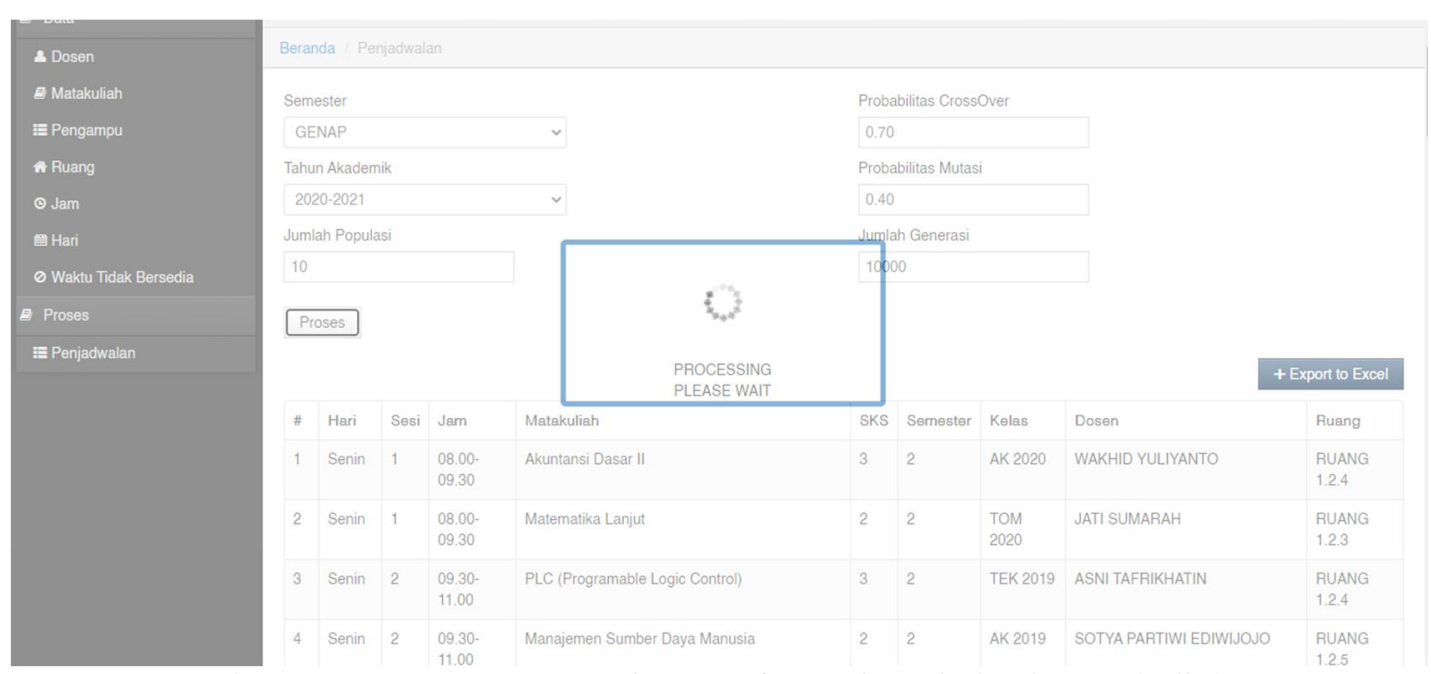

Gambar 11. Proses Generate Sistem Informasi Penjadwalan Perkuliahan

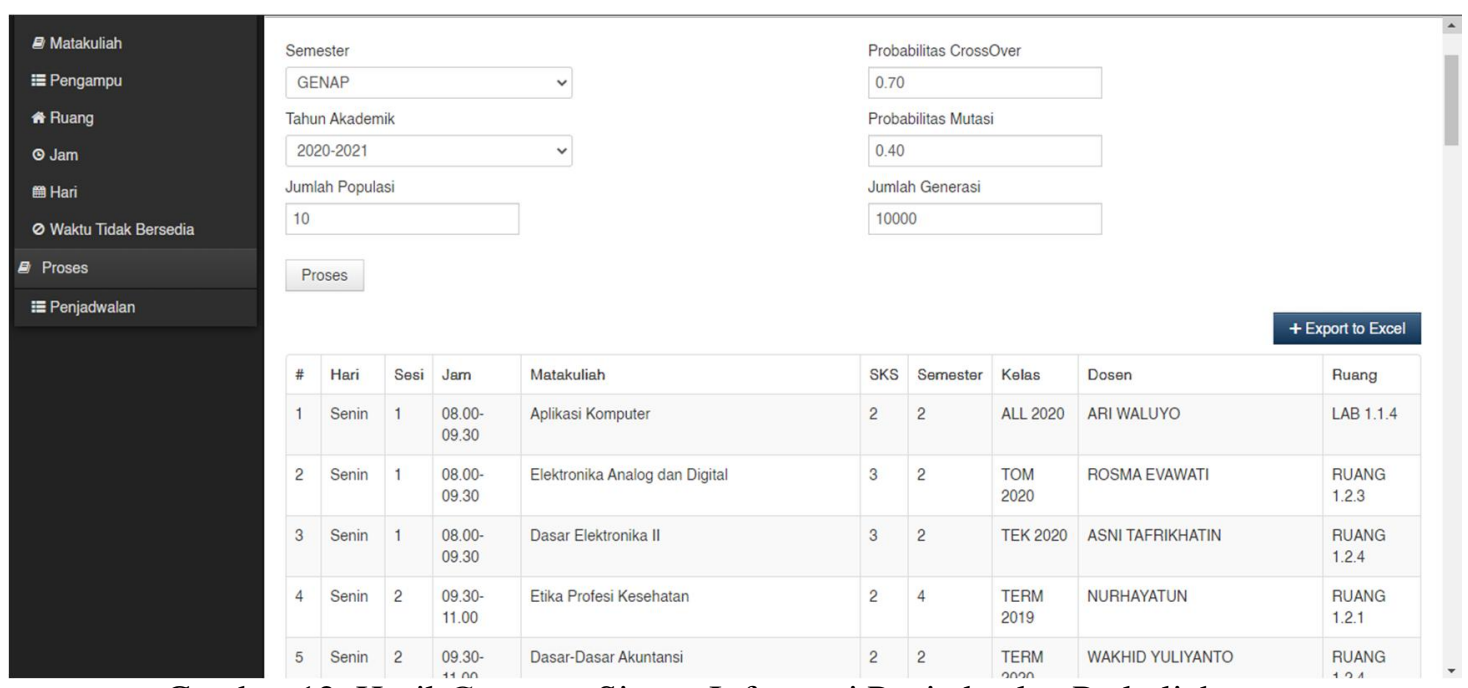

Gambar 12. Hasil Generate Sistem Informasi Penjadwalan Perkuliahan

Arif, et., al [Perancangan Sistem Penjadwalan Perkuliahan Berbasis Website Menggunakan Algortima Genetika] 
Berdasarkan hasil proses algoritma genetika didapatkan output sistem informasi penjadwalan yang terdiri atas 65 mata kuliah dengan 37 dosen pengampu yang telah terbagi sesuai dengan ketentuan hard constraint. Mata kuliah yang dijalani oleh suatu kelas pada suatu waktu telah terbagi secara acak namun tidak bertabrakan waktunya, dengan diampu oleh dosen pengampu yang sesuai dan ruangan yang tidak sama. Setelah diteliti lebih dalam, hasil output mendapatkan data yang tidak bertabrakan antara kelas, dosen pengampu, mata kuliah, waktu, dan ruangan. Hasil output sistem informasi penjadwalan ini kemudian dapat disimpan dalam bentuk database atau di export ke dalam format Excel.

\subsection{Uji Coba Waktu Komputasi}

Uji coba waktu komputasi dimaksudkan untuk mendapatkan set algoritma genetika yang menghasilkan produk berupa jadwal perkuliahan dalam waktu yang singkat, namun tetap dengan tingkat optimasi yang tinggi. Uji coba waktu komputasi ini dilakukan dengan mengubah nilai probabilitas mutasi $(\mathrm{Pm})$ dan probabilitas crossover $(\mathrm{Pc})$ ke lima nilai populasi berbeda, yakni populasi 10, 20, 30, 40, dan 50. Waktu yang dibutuhkan untuk proses penjadwalan menggunakan algoritma genetika berdasarkan perbedaan Pc dan Pm serta jumlah populasi, didapatkan data pada Tabel 2.

Tabel 2. Durasi Generate Penjadwalan Perkuliahan

\begin{tabular}{|c|c|c|c|}
\hline \multirow{2}{*}{$\begin{array}{c}\text { Jumlah } \\
\text { Populasi }\end{array}$} & \multicolumn{3}{|c|}{ Set Algoritma } \\
\cline { 2 - 4 } & $\begin{array}{c}\mathrm{Pm}=0,2 \\
\mathrm{Pc}=0,5\end{array}$ & $\begin{array}{c}\mathrm{Pm}=0,4 \\
\mathrm{Pc}=0,7\end{array}$ & $\begin{array}{c}\mathrm{Pm}=0,6 \\
\mathrm{Pc}=0,9\end{array}$ \\
\hline 10 & $00: 37: 28$ & $00: 12: 17$ & $00: 20: 47$ \\
\hline 20 & $00: 40: 12$ & $00: 24: 15$ & $00: 15: 12$ \\
\hline 30 & $00: 30: 02$ & $00: 19: 37$ & $00: 20: 51$ \\
\hline 40 & $00: 34: 13$ & $00: 25: 01$ & $00: 24: 39$ \\
\hline 50 & $00: 35: 55$ & $00: 33: 14$ & $00: 26: 12$ \\
\hline
\end{tabular}

Berdasarkan hasil uji coba waktu komputasi, didapatkan waktu paling efektif untuk proses penjadwalan perkuliahan, dengan durasi 00:12:17 adalah pada populasi dengan nilai 10 , Pm bernilai 0,4 dan Pc bernilai 0,7. Nilai ini selanjutnya akan digunakan guna mengoptimasi penjadwalan perkuliahan pada Politeknik Dharma Patria Kebumen.

\section{KESIMPULAN}

Berdasarkan analisis yang telah dilakukan pada penerapan sistem informasi penjadwalan perkuliahan di Politeknik Dharma Patria, kesimpulan yang didapatkan antara lain adalah sistem informasi penjadwalan perkuliahan yang dirancang menggunakan algoritma genetika dapat mengoptimasi proses penjadwalan dengan waktu yang relatif singkat, tanpa adanya jadwal yang bentrok. Durasi paling cepat dalam proses penjadwalan dengan algoritma genetika adalah 00:12:17 dengan nilai populasi 10, nilai Pm 0,4, dan nilai Pc 0,7. Sehingga, algoritma genetika dapat dimanfaaatkan untuk melakukan proses penjadwalan perkuliahan yang akurat, cepat, efisien, dan efektif. 


\section{SARAN}

Sistem informasi penjadwalan perkuliahan menggunakan algoritma genetika pada Politeknik Dharma Patria Kebumen masih memerlukan beberapa pengembangan untuk menjadikannya lebih akurat dan sempurna, berikut ini beberapa saran untuk penelitian selanjutnya:

1. Sistem informasi penjadwalan perkuliahan yang telah dirancang belum memperhatikan kelas weekend, sehingga kelas weekend hanya mengikuti jadwal kelas karyawan. Untuk pengembangan sistem penjadwalan selanjutnya dapat diperhatikan kembali pembagian kelas karyawan.

2. Durasi proses generate jadwal mungkin akan berbeda pada setiap perangkat keras serta koneksi internet yang digunakan, sehingga perlu diperhatikan spesifikasi minimal perangkat keras, serta kecepatan koneksi internet.

Sistem informasi penjadwalan perkuliahan masih terpisah dengan sistem informasi akademik. Alangkah baiknya jika sistem informasi penjadwalan perkuliahan dapat diintegrasikan dengan sistem informasi akademik yang telah berjalan pada Politeknik Dharma Patria Kebumen.

\section{UCAPAN TERIMA KASIH}

Penulis mengucapkan terima kasih kepada Politeknik Dharma Patria Kebumen atas kesediannya berpartisipasi dalam penelitian ini.

\section{DAFTAR PUSTAKA}

[1] D. D. Darmansah, N. W. Wardani, and M. Y. Fathoni, "Perancangan Absensi Berbasis Face Recognition pada Desa Sokaraja Lor Menggunakan Platform Android,” JATISI (Jurnal Tek. Inform. dan Sist. Informasi), Vol. 8, No. 1, pp. 91104, 2021, doi: 10.35957/jatisi.v8i1.629.

[2] N. Luh, W. Sri, R. Ginantra, I. Bagus, and G. Anandita, "Implementasi Algoritma Genetika Berbasis Web pada Sistem Penjadwalan Mengajar di SMK Dwijendra Denpasar," pp. 130-138, 2019.

[3] A. Christian, H. Sujaini, and A. B. P. Negara, "Implementasi Sistem Penjadwalan Akademik Fakultas Teknik Universitas Tanjungpura Menggunakan Metode Algoritma Genetika,” J. Sist. dan Teknol. Inf., Vol. 5, No. 2, pp. 92-99, 2017.

[4] E. Sugiarto, S. Winarno, and A. Fahmi, "Penjadwalan Perkuliahan Otomatis Berbasis Fuzzy Logic Dan Genetic Algorithm," Techno.COM, Vol. 14, No. 4, pp. 315-328, 2015.

[5] E. Suhartono, "Optimasi Penjadwalan Mata Kuliah dengan Algoritma Genetika (Studi Kasus di AMIK JTC Semarang),” Infokam, Vol. 2, pp. 132-146, 2015.

[6] A. Nugroho, W. Priatna, and I. Romli, "Implementasi Algoritma Genetika Untuk Optimasi Penjadwalan Mata Kuliah,” No. June, 2019.

Arif, et., al [Perancangan Sistem Penjadwalan Perkuliahan Berbasis Website Menggunakan Algortima Genetika] 
[7] V. N. Wijayaningrum and P. N. Malang, "Penyusunan Jadwal Asisten Praktikum Menggunakan Algoritma Genetika,” No. June, 2019, doi: 10.32520/stmsi.v8i2.501.

[8] A. Waluyo and E. V. L. N. Fatich, "Perancangan Website Dinas Pendidikan Pemuda dan Olah Raga (Studi Kasus Dinas Pendidikan Pemuda dan Olah Raga Kabupaten Kebumen), ” J-SAKTI (Jurnal Sains Komput. dan Inform., Vol. 1, No. 2, p. 186, 2017, doi: 10.30645/j-sakti.v1i2.42.

[9] D. D. Darmansah, "Perancangan Sistem Informasi Pengolahan Jadwal Mata Pelajaran Siswa Secara Online Di SMPN 31 Padang Berbasis Web," JATISI (Jurnal Tek. Inform. dan Sist. Informasi), Vol. 7, No. 3, pp. 451-465, 2020, doi: 10.35957/jatisi.v7i3.490.

[10] I. M. B. Adnyana, “Implementasi Algoritma Genetika Untuk Penjadwalan Asisten Dosen di STIKOM Bali,” J. Sist. Dan Inform., Vol. 12, No. 2, pp. 166-173, 2018.

[11] Y. Afandi and W. Setiyaningsih, "Sistem Penjadwalan Kuliah Meggunakan Metode Algoritma Genetika pada Program Magister Fakultas Ekonomi dan Bisnis," J. Terap. Sains Teknol., Vol. 1, No. 1, pp. 40-47, 2019.

[12] A. Josi, "Implementasi Algoritma Genetika pada Aplikasi Penjadwalan Perkuliahan Berbasis Web Dengan Mengadopsi Model Waterfall,” J. Inform. J. Pengemb. IT, vol. 02, No. 02, pp. 77-83, 2017, [Online]. Available: http://ejournal.poltektegal.ac.id/index.php/informatika/article/view/517/554.

[13] W. A. Puspaningrum, A. Djunaidy, and R. A. Vinarti, "Penjadwalan Mata Kuliah Menggunakan Algoritma Genetika di Jurusan Sistem Informasi ITS, ” Vol. 2, No. 1, pp. 127-131, 2013.

[14] D. Wahyuningsih and E. Helmud, "Penerapan Algoritma Genetika Untuk Optimasi Penjadwalan pada MTS Negeri 1 Pangkalpinang,” Vol. 09, No. November, pp. 435-441, 2020.

[15] W. F. Mahmudy and N. K. Mawaddah, "Optimasi Penjadwalan Ujian Menggunakan Algoritma Genetika,” No. August, 2015. 